\title{
Curing Ingredients, Characteristics, Total Phenolic, and Antioxidant Activity of Commercial Indonesian Dried Meat Product (Dendeng)
}

\author{
T. Suryatia, *, M. Astawan ${ }^{\text {b }}$, H. N. Lioe ${ }^{\mathrm{b}}$, \& T. Wresdiyati ${ }^{\mathrm{c}}$ \\ ${ }^{a}$ Major Program of Food Science, Graduate School, Bogor Agricultural University \\ ${ }^{b}$ Department of Food Science and Technology, Faculty of Agricultural Technology, Bogor Agricultural University \\ 'Department of Anatomy, Physiology and Pharmacology, Faculty of Veterinary, Bogor Agricultural University \\ Kampus IPB Darmaga, Bogor 16680, Indonesia \\ (Received 25-04-2012; accepted 19-07-2012)
}

\begin{abstract}
ABSTRAK
Dendeng merupakan produk olahan daging kering Indonesia yang menggunakan rempah-rempah kaya antioksidan sebagai bumbu. Produksi dendeng pada tingkat komersial umumnya menggunakan garam nitrat/nitrit (sendawa) sebagai bahan curing untuk menghasilkan warna merah yang stabil. Penelitian ini bertujuan untuk meneliti komposisi bumbu rempah dan garam nitrat, karakteristik, total fenolat, aktivitas antioksidan dendeng komersial. Penelitian ini dilakukan melalui wawancara dengan beberapa produsen dendeng untuk memperoleh informasi tentang penggunaan sendawa dan komposisi bumbu yang digunakan. Hasil wawancara kemudian diverifikasi dengan pengujian sampel di laboratorium. Hasilnya menunjukkan bahwa penggunaan bumbu dan sendawa bervariasi antar produsen. Penggunaan sendawa pada penelitian ini tidak selalu menghasilkan warna merah yang stabil. Total fenolik dendeng dari produsen berkisar 42,47-102,00 mg EAG/100 g BK untuk dendeng mentah, dan 36,51-95,49 mg EAG/100 g BK untuk dendeng matang. Kapasitas antioksidan terhadap DPPH berkisar 79,35-379,40 mg EVC/100 g BK untuk dendeng mentah, dan 94,30$559,40 \mathrm{mg} \mathrm{EVC} / 100 \mathrm{~g}$ BK untuk dendeng matang. Kapasitas antioksidan dendeng mentah $87,2 \%$ dipengaruhi oleh total senyawa fenolat, sedangkan pada dendeng matang hanya $59,0 \%$. Kesimpulannya adalah bahwa dendeng memiliki aktivitas antioksidan yang nyata, meskipun setelah penggorengan, dan penggunaan sendawa pada penelitian ini tidak efektif untuk menghasilkan warna merah yang konsisten pada dendeng.
\end{abstract}

Kata kunci: dendeng, total fenol, aktivitas antioksidan, karakteristik dendeng komersial

\section{ABSTRACT}

Dendeng is Indonesian dried meat product that used spices rich in antioxidant component as ingredient. In addition, commercial dendeng usually use saltpeter (nitrate/nitrite salt) as curing ingredient to inhibit rancidity and to produce stable red color. The aims of this study were to investigate composition of spices and saltpeter added, characteristic, total phenolic, and antioxidant activity of commercial dendeng. This research was conducted through interview with some dendeng producers to get information about saltpeter adding and spices composition used in their products. Then the interview results were verified by laboratory analysis. The results showed that spices and saltpeter adding from some producers varied. The saltpeter added in curing process produced inconsistent red color on commercial dendeng in this investigation. Total phenolic of dendeng from producers ranged from 42.47 to $102.0 \mathrm{mg} \mathrm{GAE} / 100 \mathrm{~g}$ DM for raw dendeng, and 36.51 to $95.49 \mathrm{mg} \mathrm{GAE} / 100 \mathrm{~g} \mathrm{DM}$ for fried dendeng. Antioxidant capacity against DPPH ranged from 79.35 to $379.40 \mathrm{mg}$ VCE/100 g DM for raw dendeng, and 94.30 to $559.40 \mathrm{mg} \mathrm{VCE} / 100 \mathrm{~g}$ DM for fried dendeng. Antioxidant capacity of raw dendeng was influenced by phenolic content about $87.2 \%$, but in fried dendeng was only $59.0 \%$. In conclusion, dendeng has a significant antioxidant activity, even after frying, and saltpeter addition was not effective to maintain stable red color in dendeng products.

Key words: dendeng (Indonesian dried meat), total phenolic, antioxidant activity, commercial dendeng characteristics

\footnotetext{
* Corresponding author:

Department of Animal Production and Technology, Faculty of Animal

Science, Bogor Agricultural University

Jln. Agatis, Kampus IPB Darmaga, Bogor 16680, Indonesia

E-mail: tutisuryati16@yahoo.com
} 


\section{INTRODUCTION}

Dendeng is traditional Indonesian dried meat product processed by added spices ingredient and drying. The ingredient added varied, but the dendeng that popular in Java has sweet and coriander flavor oriented predominantly. Bintoro et al. (1987) stated that the ingredient added in dendeng making was palm sugar, salt, coriander and caraway seed. Generally the ingredient of sweet dendeng that most popular in Java was palm sugar, white sugar, salt, garlic, coriander, galangal, sometimes tamarind, cumin and pepper was added also. Although there was no standard of ingredient for dendeng making, but the usual ingredient that used in dendeng making had antioxidant activity, such as garlic (Leelarungrayub et al., 2006; Gorienstein et al., 2008; Tangkanakul et al., 2009), coriander (Dragland et al., 2003; Tangkanakul et al., 2009), galangal (Vankar et al., 2006; Chan et al., 2008; Mahae \& Chaiseri, 2009; Tangkanakul et al., 2009), pepper and tamarind (Tangkanakul et al., 2009). Bioactive compound of garlic reported also had nitrite-scavenging and nitrosamine forming inhibition (Choi et al., 2007).

Dendeng making at industry level add saltpeter (nitrate salt) to inhibit rancidity and to produce the heat stable red color. Some research showed that ingredient and nitrate/nitrite salt on meat product besides affect color (Honikel, 2008) and flavor (Toldra et al., 2009), also affect oxidation lipid (Sebranek \& Bacus, 2007; Toldra et al., 2009). Nitrite added at curing process could form reactive compound $\mathrm{NO}$ that could bind to myoglobin and produce heat stable cure color. The NO molecule itself can easily be oxidized to $\mathrm{NO}_{2}$ in the presence of oxygen. This means an oxygen sequestering and thus the antioxidant action of nitrite in meat curing process (Honikel, 2008). Unfortunately, because of its reactivity, NO form could also react with amine primer and secondary form carcinogenic nitrosamine (Rostkowska et al., 1998; Honikel, 2008).

Previous research about dendeng generally was the laboratorium research. Buckle \& Purnomo (1986) reported browning on dendeng at laboratorium scale. Muchtadi (1987) evaluated the nutritional value of dendeng. Legowo et al. (2002) reported effect of betel leaf juice soaking on rancidity and sensory characteristic of dendeng. Chemical and microbiology analysis of dendeng samples from supermarket in Jakarta, Surabaya and Solo was reported by Bintoro et al. (1989). Spices used in dendeng need to be deeper investigated, therefore can explain the spices usage in dendeng as one of Indonesian heritage. This research intent was on exploring composition of spices and saltpeter added, characteristic, total phenolic, antioxidant activity (radical DPPH scavenging activity and antioxidant capacity against DPPH) of commercial dendeng from some producers.

\section{MATERIALS AND METHODS}

\section{Data Collecting and Sampling Method}

Information of spices and samples were collected from seven selected producers from West (producer of dendeng JB-1, JB-2, JB-3) and Central (producer of dendeng JT-1, JT-2, JT-3) Java, Indonesia. Samples produced at last batch from each producer when interviewed were analyzed to verify with interview results.

\section{Sample Preparation}

Dendeng obtained from some producers were stored in ambient temperature for a week, and then were stored in refrigerator for 3 weeks. Samples were evaluated in the form of raw and fried. Fried dendeng samples were prepared by soaking in water for $5 \mathrm{~min}$ before frying, and then after $15 \mathrm{~min}, 250 \mathrm{~g}$ of sample was fried in $2 \mathrm{~L}$ boiling vegetable oil (not over $150{ }^{\circ} \mathrm{C}$ ) for 1.5 min. Vegetables oil only used for once frying. Raw and fried samples were extracted, except for color analysis: a value, were blended and homogenized. All of samples were stored at $-25^{\circ} \mathrm{C}$ for further analysis.

\section{Analysis of a Color Value, Moisture Content and pH}

Intensity of red color (a color value), $\mathrm{pH}$ and moisture content were measured as characteristic variables of dendeng. Intensity of red color was measured by using chromameter Minolta and manifested as "a" color value. Moisture content was analyzed by using AOAC method (2005). Value of $\mathrm{pH}$ was analyzed by meat $\mathrm{pH}$ meter Hanna.

\section{Analysis of Total Phenolic and Antioxidant Activity}

Raw and fried dendeng were extracted using method described by Tangkanakul et al. (2009) with some modification in extraction stage. Amount of $1 \mathrm{~g}$ fried dendeng was extracted twice by $2.5 \mathrm{ml}$ methanol for $24 \mathrm{hr}$ at room temperature. Filtrate from both extraction was mixed and added with methanol until volume reach $10 \mathrm{ml}$. Extracts were stored in $-25^{\circ} \mathrm{C}$ until further use for analysis of total phenolic, scavenging activity on radical DPPH (from Sigma Aldrich) and antioxidant activity. Analysis of total phenolic, scavenging activity on radical DPPH and antioxidant activity were done based on procedure described by Tangkanakul et al. (2009). Antioxidant activity was determined as antioxidant capacity measured based on calibration curve inhibition of vitamin $\mathrm{C}$ at some concentration on radical DPPH.

\section{Data Analysis}

Interview and laboratory data were analyzed by using descriptive analysis. Data correlations were made between total phenolic and antioxidant capacity.

\section{RESULTS AND DISCUSSION}

\section{Curing Ingredients and Characteristics of Dendeng from some Producers}

The kind and amount of spices added in dendeng industries varied among producers. Percentage of spices added in dendeng from the producers ranged from $1.67 \%$ to $22.0 \%$ (Table 1 ). The spices generally added were garlic, coriander, and galangal. Some producers added dif- 
ferent spices such as: shallot, pepper, tamarind, cumin, cinnamon and lime. Saltpeter as nitrate salt added in curing process ranged from 1 to $5333 \mathrm{mg} / \mathrm{kg}$, and 3 of producers stated did not use saltpeter in their dendeng making. Based on Indonesian regulatory (PERMENKES RI No.722/MenKes/Per/IX/88), the maximum level of nitrate salt allowed in meat processing was $500 \mathrm{mg} / \mathrm{kg}$. Therefore 2 producers namely dendeng JB-2 dan JB-3 producers still used saltpeter above the maximum level allowed.

The red color intensity, moisture and $\mathrm{pH}$ of raw dendeng from Central Java producers were higher than those from West Java (Table 2). These facts probably correlated with dendeng drying time between these two places. Based on interview results, the dendeng producers from West Java dried their dendeng only one day (approx. $8 \mathrm{hr}$ ) in hot weather, while the dendeng producers from Central Java dried their dendeng for $3 \mathrm{~d}$ (approx. 24 hr) in hot weather. After frying process, the moisture of dendeng generally increased that was caused by soaking in the water before frying. The red color intensity of dendeng after frying decreased (Table 2), because frying process in dendeng produced non enzymatic browning as a result of Maillard reaction (Buckle \& Purnomo, 1986; Zamora \& Hidalgo, 2010). Sugar addition, especially white sugar, as dominant ingredient on dendeng processing caused Maillard reaction to be more intensive.

The saltpeter usage to produce consistent red color in dendeng was not proved in this research. Pink color as specific color of meat cured was formed by reaction between NO from nitrite or nitrate salt and meat myoglobin (Honikel, 2008). This fact was shown by dendeng JB-2 and JB-3, although the amount of saltpeter added was higher, but the red color intensity produced was lower than dendeng without saltpeter, such as dendeng JT-1 and JT-4. The red color intensity of dendeng JT-1 dan JT-4 was

Table 1. Curing ingredients used by some dendeng producers in Java

\begin{tabular}{|c|c|c|c|c|c|c|c|c|}
\hline \multirow{2}{*}{ Curing ingredients } & \multicolumn{8}{|c|}{ Dendeng } \\
\hline & JB-1 & JB-2 & JB-3 & JT-1 & JT-2 & JT-3 & JT-4 & JT-5 \\
\hline Spices (\%) & 18.13 & 1.67 & 1.69 & 13.32 & 21.00 & 21.00 & 3.15 & 7.80 \\
\hline Shallot (\%) & 10.00 & - & - & - & - & - & - & - \\
\hline Garlic (\%) & 0.63 & - & - & 4.20 & 15.00 & 15.00 & 2.00 & 2.00 \\
\hline Coriander (\%) & asf & 1.67 & 1.67 & 0.80 & 2.00 & 2.00 & 1.00 & 4.00 \\
\hline Galangal (\%) & 7.50 & - & - & 8.30 & asf & asf & - & 1.00 \\
\hline Tamarind (\%) & - & - & 0.02 & - & asf & asf & - & - \\
\hline Pepper (\%) & - & - & - & 0.02 & - & - & 0.05 & - \\
\hline Cinnamon (\%) & - & - & - & - & 2.00 & 2.00 & - & - \\
\hline Cumin $(\%)$ & - & - & - & - & 2.00 & 2.00 & 0.05 & 0.40 \\
\hline Lime (\%) & - & - & - & - & - & - & 0.05 & 0.40 \\
\hline Salt peter (mg/kg) & - & $3,333.00$ & $5,333.00$ & - & 1.00 & 1.00 & - & 200.00 \\
\hline Palm sugar (\%) & 40.00 & 20.00 & 6.70 & 33.30 & 35.00 & 35.00 & 5.00 & 22.50 \\
\hline White sugar (\%) & - & 10.00 & 10.00 & - & - & - & 20.00 & 7.50 \\
\hline Cooking salt (\%) & 3.13 & 0.25 & 2.33 & asf & asf & asf & 3.00 & - \\
\hline
\end{tabular}

Note: Data based on interview with 7 dendeng producers. JB-1, JB-2 and JB-3 were dendeng from West of Java; JT-1, JT-2, JT-3, JT-4 and JT-5 were dendeng from Central of Java; asf= at sufficiently; percentage of ingredient based on meat weight.

Tabel 2. Red color intensity, moisture content and $\mathrm{pH}$ of raw and fried dendeng from some producers in West and Central of Java

\begin{tabular}{|c|c|c|c|c|c|c|c|}
\hline \multirow{2}{*}{ No. } & \multirow{2}{*}{ Sampel } & \multicolumn{2}{|c|}{ Red color intensity (a) } & \multicolumn{2}{|c|}{ Moisture (\%) } & \multicolumn{2}{|c|}{$\mathrm{pH}$} \\
\hline & & Raw & Fried & Raw & Fried & Raw & Fried \\
\hline 1 & JB-1 & 7.88 & 8.89 & 33.09 & 31.87 & 5.46 & 5.74 \\
\hline 2 & JB-2 & 8.01 & 5.57 & 18.78 & 23.29 & 5.51 & 5.61 \\
\hline 3 & JB-3 & 9.45 & 7.88 & 29.45 & 29.38 & 5.66 & 5.90 \\
\hline 4 & JT-1 & 11.18 & 5.57 & 15.03 & 20.65 & 5.24 & 5.51 \\
\hline 5 & JT-2 & 12.32 & 5.74 & 14.12 & 21.19 & 5.13 & 5.21 \\
\hline 6 & JT-3 & 14.78 & 9.99 & 13.57 & 18.89 & 5.32 & 5.56 \\
\hline 7 & JT-4 & 14.26 & 8.90 & 14.59 & 23.33 & 5.22 & 5.66 \\
\hline 8 & JT-5 & 13.91 & 8.73 & 13.62 & 20.84 & 5.26 & 5.82 \\
\hline
\end{tabular}

Note: JB-1, JB-2 and JB-3 are dendeng from West of Java; JT-1, JT-2, JT-3, JT-4 and JT-5 are dendeng from Central of Java. 
not different with dendeng JT-2, JT-3 and JT-5 that used saltpeter in their manufactured (Table 2). This fact could be related with $\mathrm{NO}$ formation from saltpeter component and its interaction with antioxidant from spices. If $\mathrm{NO}$ form in dendeng was stabilized by antioxidant from spices, meat myoglobin could not react with $\mathrm{NO}$, and the pink color as specific color of meat cured could not be formed.

\section{Total Phenolic and Antioxidant Activity on Raw and Fried Dendeng from Some Producers}

Total phenolic content of dendeng from some producers (Figure 1) did not correlate with percentage of spices added (Table 1). This was probably caused by the differences in total phenolic of each spices used. Dendeng JB-1 had the highest total phenolic content, followed by dendeng JT-1, JT-5, JT-3, JT-2, JT-4, JB-3, and JB-2. Although dendeng JB-1 used lower percentage spices than dendeng JT-2 and JT-3, but the spices added, such as shallot, galangal and coriander had phenolic content higher than garlic (Tangkanakul et al., 2009) used predominantly at dendeng JT-2 and JT-3. This explained why the dendeng JB-1 had the highest total phenolic.

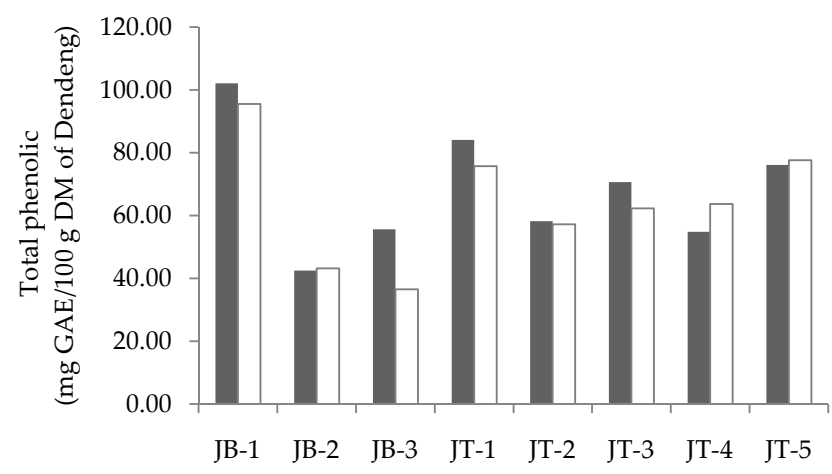

Figure 1. Total phenolic content of dendeng ( $\square$ : raw and $\square$ : fried) from some producers. JB-1, JB-2 and JB-3 were dendeng from West of Java; JT-1, JT-2, JT-3, JT-4 and JT-5 were dendeng from Central of Java.

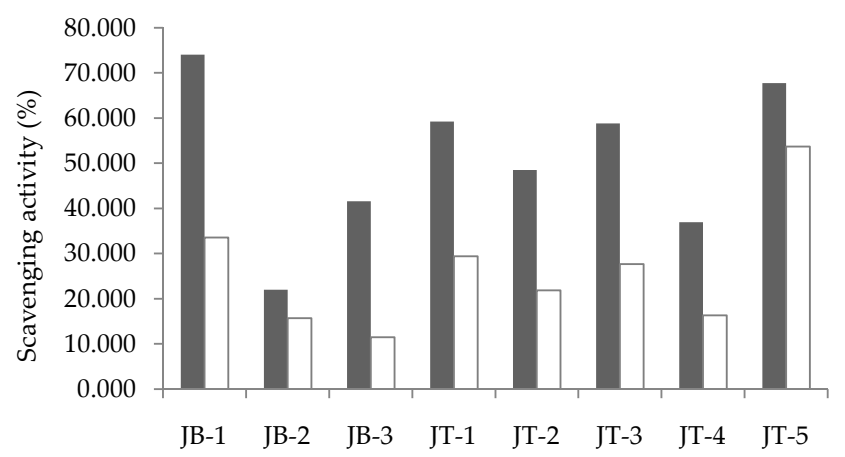

Figure 2. Scavenging activity on DPPH of dendeng ( $\mathbf{m}$ : raw and $\square$ : fried) from some producers. JB-1, JB-2 and JB-3 were dendeng from West of Java; JT-1, JT-2, JT-3, JT-4 and JT5 were dendeng from Central of Java.
The activity of raw dendeng to scavenge radical DPPH was higher than fried dendeng (Figure 2). This fact showed that frying process decreased the activity of dendeng spices to scavenge radical DPPH. The mechanism could be explained that the frying process induced lipid oxidation (Baardseth et al., 2005; Choe \& Min, 2007) that produced radical compounds as primer product of the reaction (Min \& Ahn, 2005). These radical compounds could react with antioxidant compounds contained in dendeng that gave benefit as the inhibiting of lipid oxidation.

The antioxidant activity that measured as antioxidant capacity of all dendeng, except JB-3, increased after frying (Figure 3). These data had different pattern with scavenging against DPPH data; because antioxidant activity was determined by calculating the sample weight and moisture. The antioxidant capacity of dendeng JB-1 either raw or fried was higher than others, except fried JT-5. Tangkanakul et al. (2009) divided the activity of antioxidant of products based on antioxidant capacity into four groups: very high (> $500 \mathrm{mg} \mathrm{VCE} / 100 \mathrm{~g}$ ), high (200-500 mg VCE/100 g), medium (100-200 mg VCE/100 g) and low (< $100 \mathrm{mg}$ VCE/100 g). Based on that classification, the antioxidant activity of raw dendeng JB-1, JT-1, JT-3 and JT-5 were high; JB-3, JT-2 and JT-4 were medium; while JB-2 was low. These conditions changed after frying, in which dendeng JT-5 was very high; JB-1, JT-1 and JT-3 were consistent high; JT-2 changed to high; JT-4 was still medium; while JB-2 and JB-3 changed to medium and low respectively.

The antioxidant activity of fried dendeng generally increased from the raw ones, except for dendeng JB-3. This indicated that antioxidant activity of dendeng was not only caused by spices antioxidant component, but also could be caused by formation of antioxidant component from nitrate salt or nitrite generated from saltpeter (Sebranek \& Bacus, 2007; Honikel, 2008), and Maillard product that had antioxidant activity (Yilmas \& Toledo, 2005; Gu et al., 2010; Sun et al., 2010; Zhuang \& Sun, 2011; Dong et al., 2012; Miranda et al., 2012). Antioxidant activity of dendeng JB-3 was only affected by antioxidant component from spices that could be compared with total phenolic and scavenging activity on DPPH that also decreased after frying. Saltpeter added and Maillard

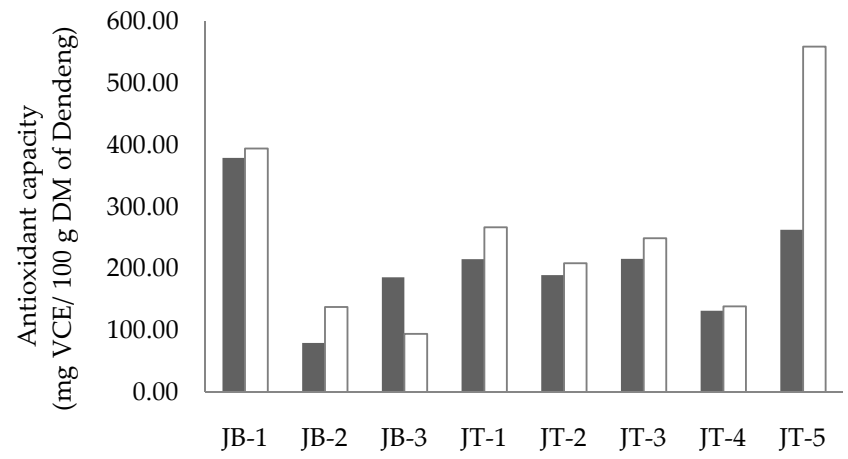

Figure 3. Antioxidant capacity of dendeng ( $\mathbf{m}$ : raw and $\square$ : fried) from some producers. JB-1, JB-2 and JB-3 were dendeng from West of Java; JT-1, JT-2, JT-3, JT-4 and JT- 5 were dendeng from Central of Java. 


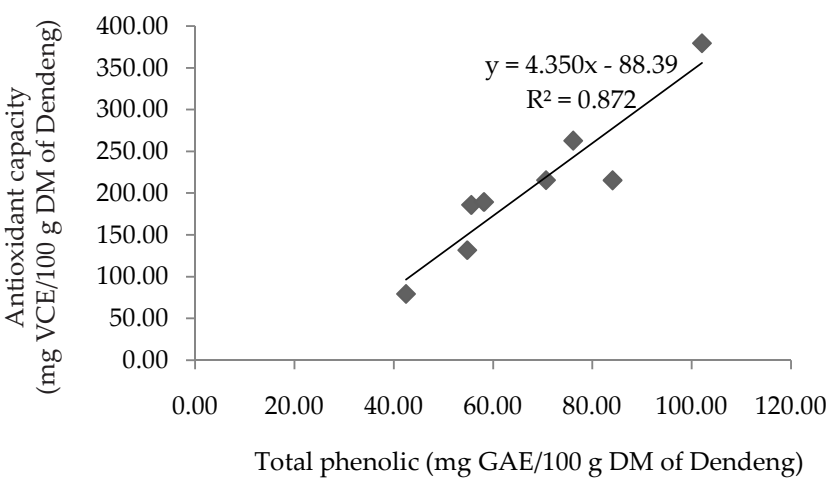

Figure 4. Correlation of total phenolic and antioxidant capacity of raw dendeng from some producers

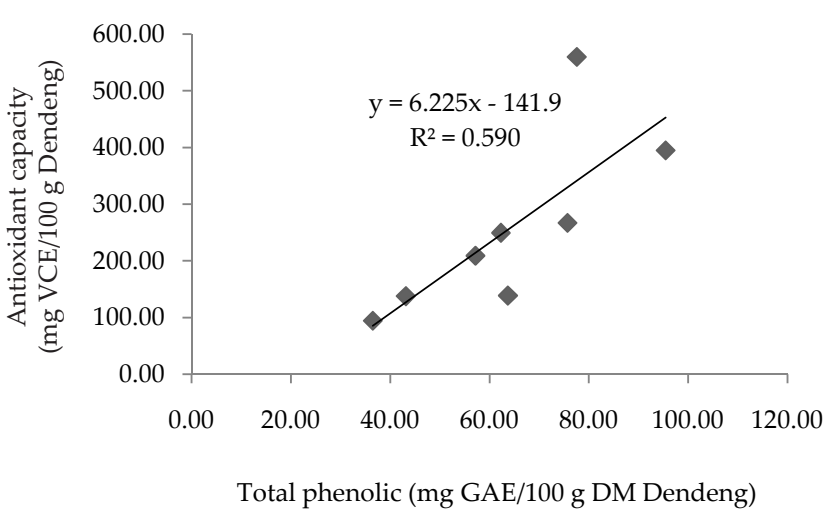

Figure 5. Correlation of total phenolic and antioxidant capacity of fried dendeng from some producers

product resulted in this dendeng were not contributed to its antioxidant activity. Based on Figure 1, 2 and 3, although the scavenging activity on DPPH decreased after frying, when total phenolic did not decrease significantly and used the optimum nitrate salt in curing process, the antioxidant activity would not decrease after frying.

Total phenolic compound affected significantly $(\mathrm{P}<0.01)$ antioxidant capacity of raw dendeng followed regression linier: $y=4.350 X-88.39$; with $R^{2}=0.872$ (Figure 4 ). Based on coefficient determination of the li-near regression implicated that $87.2 \%$ antioxidant capacity of raw dendeng was influenced by its total phenolic content, and $12.8 \%$ was influenced by others. The other factor could be NO from nitrate salt. Antioxidant activity of fried dendeng was different from raw dendeng, although regression linear between total phenolic and antioxidant capacity (Figure 5) was significant $(P<0.01)$, but its coefficient determination was lower $\left(R^{2}=0,590\right)$ than raw dendeng. This indicated that antioxidant capacity of fried dendeng, 59.0\% was affected by its total phenolic, and $41.0 \%$ was affected by other factors. Coefficient determination of linear regression in raw and fried dendeng was strong indication that the antioxidant activity in dendeng was not only caused by spice added, but also could be caused by oxidized NO from saltpeter added and Maillard product in dendeng.

\section{CONCLUSION}

The kind and amount of spices added in dendeng industries varied among producers and ranged from $1.67 \%$ to $22.0 \%$ with the main spices were garlic, coriander, and galangal. Total phenolic content of dendeng do not correlate to percentage of spices added. Saltpeter as nitrate salt added in curing process ranged from 0 to $5333 \mathrm{mg} / \mathrm{kg}$, but in this investigation it was not effective to maintain stable red color in dendeng products. Dendeng products have significant antioxidant activity, even after frying.

\section{ACKNOWLEDGEMENT}

This research was funded by BPPS Program from Directorate General of Higher Education, Ministry of Culture and Education, Indonesia. Great thank to Eka Kurniawati, S.Pt., Nielma Kartika Dewi, S.Pt., and Ari Nurhayati, S.Pt. as mediator to dendeng producers.

\section{REFERENCES}

[AOAC] Association of Official Analytical Chemists. 2005. Official Methods of Analysis of the Association of Official Analytical Chemists. Washington D.C: Agricultural Chemistry.

Baardseth, P., F. Bjerke, K. Aaby, \& M. Mielnik. 2005. A screening experiment to identify factors causing rancidity during meat loaf production. Eur. Food Res. Technol. 221: 653-661. http://dx.doi.org/10.1007/s00217-005-0061-7

Bintoro, P., J. I. Morit, K. Mikawa, \& T. Yasui. 1987. Chemical and microbiology analysis of an Indonesian dried beef (dendeng sapi). J. Fac. Agr. Hokkaido Univ. 63: 287-292.

Buckle, K. A. \& H. Purnomo. 1986. Measurement of non-enzymic browning of dehydrated and intermediate moisture meat. J. Sci. Food Agric. 37: 165-172. http://dx.doi. org/10.1002/jsfa.2740370211

Chan, E. W. C., Y. Y. Lim, L. F. Wong, F. S. Lianto, S. K. Wong, L. L. Lim, C. E. Joe, \& T. Y. Lim. 2008. Antioxidant and tyrosinase inhibition properties of leaves and rhizomes of ginger species. Food Chem. 109: 477-483. http://dx.doi. org/10.1016/j.foodchem.2008.02.016

Choe, E. \& D. B. Min. 2007. Chemistry of deep-fat frying oils. J. Food Sci. 72: R77-R86. http://dx.doi.org/10.1111/j.17503841.2007.00352.x

Choi, S. Y., M. J. Chung, S. J. Lee, J. H. Shin, \& N. J. Sung. 2007. $N$-nitrosamine inhibition by strawberry, garlic, kale, and the effects of nitrite-scavenging and $N$-nitrosamine formation by functional compounds in strawberry and garlic. Food Control 18 :485-491. http://dx.doi.org/10.1016/ j.foodcont.2005.12.006

Dong, S., A. Panya, M. Zeng, B. Chen, D. J. McClements, \& E. A. Decker. 2012. Characteristics and antioxidant activity of hydrolyzed $\beta$-lactoglobulin-glucose Maillard reaction products. Food Res. 46: 55-61. http://dx.doi.org/10.1016/ j.foodres.2011.11.022

Dragland, S., H. Senoo, K. Wake, K. Holte, \& R. Blomhoff. 2003. Several culinary and medicinal herbs are important sources of dietary antioxidants. J. Nutr. 133: 1286-1290.

Gorienstein, S., H. Leontowicz, M. Leontowicz, J. Namiesnik, K. Najman, J. Drzewiecki, M. Cvikrova, O. Martincova, E. Katrich, \& S. Trakhtenberg. 2008. Comparison of the main bioactive compounds and antioxidant activities in garlic and white and red onions after treatment protocols. J. Agric. Food Chem. 56: 4418-4426. http://dx.doi. org/10.1021/jf800038h 
Gu, F.-L.., J. M. Kim, S. Abbas, X.-M. Zhang, S.-Q. Xia, \& Z.-X. Chen. 2010. Structure and antioxidant activity of high molecular weight Maillard reaction product from casein-glucose. Food Chem. 120: 505-511. http://dx.doi.org/10.1016/ j.foodchem.2009.10.044

Honikel, K. O. 2008. The use and control of nitrate \& nitrite for the processing of meat products. Meat Sci. 78: 68-76. http:// dx.doi.org/10.1016/j.meatsci.2007.05.030

Leelarungrayub, N., V. Rattanapanone, N. Chanarat, \& J. M. Gebicki. 2006. Quantitative evaluation of the antioxidant properties of garlic and shallot preparations. Nutr. 22: 266-274. http://dx.doi.org/10.1016/j.nut.2005.05.010

Legowo, A. M., Soepardi, R. Miranda, I. S. N. Anisa, \& Y. Rohidayah. 2002. Pengaruh perendaman daging pra kyuring dalam jus daun sirih terhadap ketengikan dan sifat organoleptik dendeng daging sapi selama penyimpanan. J Teknol. dan Industri Pangan 13: 64-69.

Mahae, N. \& S. Chaiseri. 2009. Antioxidant activities and antioxidative components in extracts of Alpinia galanga (L.) Sw. Kasetsart J. (Nat. Sci.) 43: 358-369.

Min, B. \& D. U. Ahn. 2005. Mechanism of lipid peroxidation in meat and meat products -A review. Food Sci. Biotechnol. 14: $152-163$.

Miranda, L. T., C. Rakovski, \& L. M. Were. 2012. Effect of Maillard reaction products on oxidation products in ground chicken breast. Meat Sci. 90:352-360. http://dx.doi. org/10.1016/j.meatsci.2011.07.022

Muchtadi, D. 1987. Studies "dendeng", an Indonesia traditional preserved meat product. II. nutritional value and mutagenic effect by bioassay. Forum Pascasarjana 10: 1-10.

PERMENKES. Peraturan Menteri Kesehatan Nomor 722/Menkes/Per/IX/1988 tentang Bahan Tambahan Makanan. Departemen Kesehatan RI, Jakarta.

Rostkowska, K., K. Zwierz, A. Rozanski, J. Moniuszko-Jakoniuk, \& A. Roszczenko. 1998. Formation and metabolism of N-nitrosamines. Polish J. Environ. Studies 7: 321-325.
Sebranek, J. G. \& J. N. Bacus. 2007. Cured meat products without direct addition of nitrate or nitrite: what are the issue? Meat Sci. 77: 136-147. http://dx.doi.org/10.1016/ j.meatsci.2007.03.025

Sun, W., M. Zhao, C. Chui, Q. Zhao, \& B. Yang. 2010. Effect of Maillard reaction products derived from the hydrolysate of mechanically deboned chicken residue on antioxidant, textural, sensory properties of Cantonese sausage. Meat Sci. 86: 276-282.

Tangkanakul, P., P. Auttaviboonkul, B. Niyomwit, N. Lowvitoon, P. Charoenthamawat, \& G. Trakoontivakorn. 2009. Antioxidant capacity, total phenolic content and nutritional composition of Asian foods after thermal processing. Intern. Food Res. J. 16: 571-580.

Toldra, F., M. C. Aristoy, \& M. Flores. 2009. Relevance of nitrate and nitrite in dry-cured ham and their effects on aroma development. Grasas Y Aceites 60: 291-296 (Special Issue). http://dx.doi.org/10.3989/gya.130708

Vankar, P. S., V. Tiwari, L. W. Singh, \& N. Swapana. 2006. Antioxidant properties of some exclusive species of zingiberaceae family of Manipur. Electron. J. Environ. Agric. Food Chem. 5: 1318-1322.

Yilmaz, Y. \& R. Toledo. 2005. Antioxidant activity of water-soluble Maillard reaction products. Food Chem. 93: 273-278. http://dx.doi.org/10.1016/j.foodchem.2004.09.043

Zamora, R \& F. J. Hidalgo. 2010. Coordinate contribution of lipid oxidation and Maillard reaction to the nonenzymatic food browning. Critical Rev. in Food Sci. Nutr. 45:49-59. http://dx.doi.org/10.1080/10408690590900117

Zhuang, Y. \& L. Sun. 2011. Antioxidant activity of Maillard reaction products from lysine-glucose model system as related to optical property and copper (II) binding ability. Afr. J. Biotechnol.10: 6784-6793. 